\title{
AN ALTERNATIVE THEORY FOR EXCHANGE RATE DETERMINATION
}

\author{
Leonardo Fernando Cruz Basso* \\ Deparment of Economics, Mackenzie Presbyterian University
}

(Received 2 september 2001, accepted 15 december 2001)

\begin{abstract}
Why should fiat money have some value? This is one of those puzzles that economic theorists pose for themselves. Even more mysterious is the relative value (exchange rate) between fiat moneys, none of which has intrinsic value. Since money is a creature of governments, it is not surprising to find some kind of regulation to make it work. My proposal determines the relative value (exchange rate) between fiat moneys based on the currency value concept formulated by Rudolf Hilferding (1981). The currency value is then defined as the ratio between the Gross Domestic product (GDP) and the number of working hours spent to produce it. The exchange rate is defined as the ratio of the currency values between two countries. The novelty of this viewpoint is that prices and productivity are explicitely present in the model, contrary to the theory of the purchasing power parity (PPP), where productivity is included in the prices.
\end{abstract}

\section{Resumen}

¿Por qué el dinero debe tener algún valor? Este es uno de esos enigmas que los economistas teóricos se plantean a sí mismos. Es todavía más misterioso el valor relativo (tipo de cambio) entre dos monedas distintas, ninguna de las cuales tienen valor intrínseco. Dado que el dinero es creado por los gobiernos, no es sorprendente encontrar algún tipo de regulación para que éste funcione. Mi propuesta determina el valor relativo (tipo de cambio) entre monedas distintas con base en el concepto de valor del dinero formulado por Rudolf Hilferding (1981). El valor del dinero es definido como la razón entre el Producto Interno Bruto (PIB) y el número de horas para producirlo. El tipo de cambio se define entonces como la razón entre los valores del dinero de dos países. La contribución de este enfoque es que tanto los precios como la productividad están presentes en el modelo, en contraste con la Teoría de la Paridad de Poder de Compra (PPP), donde la productividad es incluida en los precios.

JEL Classification: F31, E41.

Keywords: Foreign exchange, Money demand, Labor theory of value, Productivity.

* Department of Economics, Mackenzie Presbyterian University, Rua da Consolação, 896, 6o andar, São Paulo, Brasil, Cep: 01302-907, Telephone: (55)(11)32368597, E-mail: leonardobasso@mackenzie.com.br.

The author wishes to thank two anonymous referees of this journal for valuable guidance and suggestions. 


\section{Introduction}

Some issues have remained dormant in our minds for years, many of which we do not consider as immediately important, until one day the reality around us turns the solution for them into a matter of great urgency. This took place when "plano real" was implemented. This plan allowed the elimination of under valuation that contributed to destroy prior stabilization plans, such as the "cruzado". But when we need to change the currency of one country, as we did in Brazil, we also need an answer to a crucial question: What is the exchange rate for the new currency to start with? (Here we assume the existence of a hegemonic currency, the dollar, and the need to define only one essential/primordial exchange rate).

Brazil launched "plano real" causing problems to the trade balance. Some economists regard the initial rate as an irrelevant matter, arguing that, as the economy grows, we would realize that it is not the equilibrium exchange rate, so as to alter it. Nevertheless, this is not an easy task, for the occurrence of a trade balance unsteadiness may be gradually eliminated (exchange rate "minidevaluation"), or abruptly (exchange rate "maxi-devaluation") with distinct results on internal prices (the "maxi-devaluation" may imply an increase in inflation).

In a former article (Basso, 1995), I had already criticized the one-toone parity which was "plano real" starting parity. Franco (1995) did not attribute any importance to the overvaluation concept in the described situation. Franco's criticism (Franco, 1998) of my macroeconomic argumentation for the determination of the exchange rate only enhanced my conviction that I did not make myself understood, for his argumentation is structured within a microeconomic framework ${ }^{1}$.

The reading of a Tobin's recent article (1998) increased my conviction in formalizing the theory. Contrary to the Nobel Prize winner's belief, I do believe that it is possible to present a theory for the exchange rate, based on an objective measure which does not rely on each individual's subjective utility referential. As it will be emphasized, this theory is based on an alternative concept for the currency value as explored in Basso (1987) and (1988), inspired by Rudolf Hilferding's (1982) work. Dumenil (1980) and Foley (1982) presented a rigorous algebraic formulation of the concept in the framework of the labour theory of value. The work itself is in an embryonic stage and our goal is to submit it to a broad discussion.

Our referential, as it will be highlighted, is based on a dynamic analysis, therefore it moves aside from static equilibrium models. In other words, growth rates and tendencies are more important than values in a specific point in time. The work must be critically assessed as far as its internal consistency

1 The inflation stabilization programs in Argentina, Brazil, Chile, Uruguay, and Israel, in the 1970 s and 1980s, have been widely documented; see, for instance, Calvo and Végh (1998). The Mexican case is analyzed in Venegas-Martínez (2001). 
is concerned as well as its capacity to explain the phenomenon to which it applies, for only then, it will be possible to establish whether it is relevant or needs to be replaced by another internally-consistent system which is capable to explain the behavior of relevant-economic variables for the functioning of the capitalist-production system.

The paper is organized as follows. In the next section, we work out an alternative theory for exchange rate determination. In section 3 , we include the role of the expectations in our proposal. Finally, in section 4, we present conclusions and make suggestions for further research.

\section{An alternative theory}

The theory which we are about to present is an alternative to the hypothesis of purchasing power parity, although it is quite similar to this in terms of structure. The purchasing power parity theory is a combination of two hypotheses (equations) emerged from the modern macroeconomic approach to the monetary theory (law of one price) and the quantitative theory. The law of one price is based on the assumption that the international commerce does eliminate the differences in the prices of commercialized commodities. Referring to Lindert and Kindleberger (1983):

"It frequently occurs to economists that the merchandises which are substituted by others in the international commerce should have similar price movements in all countries, when measured in terms of the same currency".

This would be true for a sufficiently long period, enough for the market equilibrium to be reached after great shocks. Suppose that wheat costs $\$ 4.00$ per sack in Chicago. Its price in US dollars in London should be higher due to the decrease in price for transportation of the wheat from Chicago to London. To simplify the example: let us say that there will be zero value in the transportation of the wheat. It seems reasonable to suppose, therefore that the price of this same wheat in London should be $\$ 4.00$ per sack. Otherwise, it would be advantageous to commercialize the wheat between Chicago and London in order to profit with the price variation. Now, if some greater rupture temporarily forces the price of wheat in London upwards to $\$ 4.80$, the free commerce still being possible, certainly one would expect the two prices to be forced toward equality, probably around $\$ 4.00$ to $\$ 4.80$, for both countries. In the case of wheat, which is a standardized commodity with the well established market, it is expected that both prices be aligned within a week (Kindleberger, 1982).

The above example illustrates the forecasting that must be done concerning transportation costs, tariff, and taxes. Besides, we must be aware of what we want to say by commerciable merchandises, since, it is crucial for the construction of our price indexes. The parity hypothesis of the purchasing power may be expressed by the formula:

$$
e=P / P^{*}
$$


where $e$ is the nominal exchange rate, and $P$ and $P^{*}$ are price indexes of commerciable merchandises (tradeable goods) in the domestic and foreign economies, respectively. The quantitative theory must enter in the picture, since, even though there is a relationship between prices and exchange rate, we need an explanation on how prices are determined. A summary of one of the versions of the theory is the following: from the supply's part, it is considered that the monetary authorities are capable of controlling the money supply, as it controls the private bank system reserves; from the demand's part it is emphasized that people are willing to perform transactions as a proportion of their incomes and the same must be true for economy as a whole. This demand may be written as a proportion of GNP (Gross National Product).

As internal conditions of equilibrium, we may write for the domestic and foreign countries

$$
M=M_{d}=K P Y=M_{s}, \quad \text { and } \quad M^{*}=M_{d}^{*}=K^{*} P^{*} Y^{*}=M_{s}^{*}
$$

where $M$ and $M^{*}$ stand for domestic and foreign currency, $Y$ and $Y^{*}$ for domestic and foreign income, and $K$ and $K^{*}$ for domestic and foreign velocities of money. If we also assume that:

a) real national products (constant prices) are ruled by the strength of supply, such as improvements in productivity, weather conditions, etc.;

b) the emergence (supply) of a currency which can be controlled by the monetary authorities;

c) $K$ and $K^{*}$ are set for individual countries.

We may find, from (1) and (2), a relationship between the supply of currency and the price levels; this combined with the law of prices provides the exchange rate determination:

$$
e=\frac{P}{P^{*}}=\left(\frac{M}{K Y}\right) /\left(\frac{M^{*}}{K^{*} Y^{*}}\right) .
$$

The test of this hypothesis has brought about some contradictory results. The empirical support is reasonable in the long run, but not in the short run.

Furthermore, there is the arbitrariness of the chosen price index. In the 70 s, this approach was given a new look under the focus known as monetary approach for the exchange rate. This emphasis was developed as an answer to the growing flexibility of the exchange rates faced by the majority of the industrialized countries after the Bretton Woods Treaty was broken. We are going to present it here because this approach makes explicit the interdependency between domestic and foreign economies, a sine qua non characteristic of our model. Its authors believed that, the exchange rate should be determined by the force of supply and demand and since the involved relative price is that between 
two currencies, it should be related to the supply and demand of the two currencies. More specifically, to support the equilibrium of the internal/domestic monetary market the existing supply must be equal to the demand.

$$
\frac{M}{P}=L(i, Y)
$$

where $M / P$ represents the real monetary balances and $i$ the nominal interest rate (see, for instance, Dornbusch, 1994). Similarly, the condition of the foreign monetary market equilibrium is given by:

$$
\frac{M^{*}}{P^{*}}=L^{*}\left(i^{*}, Y^{*}\right) .
$$

Notice that the conditions of equilibrium of the monetary market in equation (5) do not explicitly show how the exchange rate of the equilibrium is established. To do this, we have to consider an additional relationship that explicitly determines how the exchange rate affects the equilibrium of the monetary market. Consider first, the absolute purchasing power parity theory expressed as:

$$
e=\frac{P}{P^{*}} .
$$

This relationship implies that the exchange rates may affect the equilibrium of the monetary market by means of the connections that they present between domestic and foreign prices. After substituting equations (4) and (5) in (6), we get:

$$
e=\left(\frac{M}{M^{*}}\right) \frac{L^{*}\left(i^{*}, Y^{*}\right)}{L(i, Y)} .
$$

Being the relative price of two factors, the exchange rate does not depend only on the supply and demand of domestic currency, but also on the supply and demand of the foreign currency. Exchange rates cannot, therefore, be determined independently of the behavior of foreign economies or from actions taken by foreign governments. Questions related to the fluctuations concerning exchange rate must be addressed within a context of common dialogue between the countries involved. This illustrates well that, in general, a non-open economy may completely divorce itself from foreign influence. The similarity of our theory with this last version of the purchasing power parity hypothesis is, as we expect, that for a long-run result one should not expect the same price for values of similar use, but prices (no matter what currency) for the same time of social work. One additional advantage for our approach is that it may be considered as an estimator of future exchange rates, taking into consideration price oscillations and the productivity of labor. On the other hand, the purchasing power theory completely omits all the factors that take place at the level of production, emphasizing primarily in the movements of money supply. If any credit may be given to our theory, the process that explains the exchange rate between two currencies is the following: let us assume two countries with such a work force that they present the same expressed productivity in quantity of merchandise per hour of work. Identical productivities lead to the same value. 
In case the countries differ from each other for having distinct currencies, the exchange rate should be the same in order not to contradict the relation of values. This relation of productivity for one country may be expressed by the ratio between $G D P$ and the hours of work needed to produce it. Notice, however, that the GDP is expressed by the multiplication of a price index and a quantity index, and we know that prices are going to be affected by many factors. In spite of this, a country that continuously presented a smaller productivity than another would be kept out of the market, for this reason we should expect that the productivity multiplied by the price index may not be distinct. Formalizing it in mathematical terms:

$$
\frac{G D P}{N}=e \frac{G D P^{*}}{N^{*}}
$$

in which $N$ means working hours to produce the gross domestic product. Assuming that we are working with manufactured goods, the $G D P$ may be expressed by the multiplication of a price index $P$ by a quantity index $Q$. That is,

$$
P \frac{Q}{N}=e P^{*} \frac{Q^{*}}{N^{*}} .
$$

Since the division of quantities by hours of labor, it is nothing more than productivity, we obtain:

$$
P \beta=e P^{*} \beta^{*}
$$

where $\beta$ denotes productivity. This, in turn, implies

$$
e=\frac{P \beta}{P^{*} \beta^{*}} \text {. }
$$

This equation shows, for instance, that if we assume that the US productivity is twice as much that of Brazil, then the Brazilian prices should be twice those of the United States to maintain a unitary exchange rate.

Another interesting aspect of the equation is that it accepts price alterations by factors other than productivity. This enables us to incorporate all the arsenal developed by theorists of the monetary approach for the exchange rate determination. In this way, it is also possible to eliminate uncertainties that economists are not able to solve, since the exchange rate is connected to the economic productivity. However, it is important to observe productivity measured by a homogeneous referential (of labor) and not physical productivity. Our equation may be expressed in dynamic terms such as:

$$
\widehat{e}=\widehat{P}+\widehat{\beta}-\widehat{P}^{*}-\widehat{\beta}^{*}
$$

or

$$
\widehat{e}=\left(\widehat{P}-\widehat{P}^{*}\right)+\left(\widehat{\beta}-\widehat{\beta}^{*}\right)
$$

where the symbol "^" represents proportional changes for the variables being considered. In other words, if only productivity were a determinant of price, 
higher American productivity vis-a-vis Brazilian productivity, would be compensated by higher Brazilian prices, not being necessary any alteration in the exchange rate. However, it is important to keep one thing clear: our approach is not only concerning productivity, for it takes into account other macroeconomic variables, such as money supply, money demand, interest rate, and inflation expectations.

According to the monetary approach, changes in price will affect the exchange rates. Thus, affecting the equilibrium of the monetary market. The equation of equilibrium between supply and demand for money may be written in terms of proportional variations,

$$
\begin{gathered}
\widehat{P}=\frac{\Delta P}{P} ; \quad \widehat{L}=\frac{\Delta L}{L} ; \quad \widehat{M}=\frac{\Delta M}{M} ; \\
\widehat{M}-\hat{P}=\widehat{L} ; \\
\widehat{M}^{*}-\widehat{P}^{*}=\widehat{L}^{*}
\end{gathered}
$$

Expressing these relationships in terms of domestic and foreign inflation, $\widehat{P}=$ $\widehat{M}-\widehat{L}$ and $\widehat{P}=\widehat{M}^{*}-\widehat{L}^{*}$, respectively and substituting in the dynamic version of the equation of the purchasing power parity theory, we obtain: $\widehat{e}=\widehat{P}-\widehat{P}^{*}$, equivalently,

$$
\widehat{e}=\left(\widehat{M}-\widehat{M}^{*}\right)+\left(\widehat{L}^{*}-\widehat{L}\right) .
$$

In other words, variations in the exchange rate $\widehat{e}$ are determined through the changes in the relative rates of growth of suply of currencies, $\widehat{M}-\widehat{M}^{*}$, and variations in the relative rates of growth of the demand for money, $\widehat{L}^{*}-\widehat{L}$. Variations in the relative supply of currencies reflect the monetary policies of countries. Variations in relative demand for currencies, on the other hand, reflect changes in the variables which affect the currency quantity, specifically income and interest rates. Most of works that follow the monetary approach, assume that,

$$
\widehat{L}^{*}-\widehat{L}=\phi\left(\widehat{Y}^{*}-\widehat{Y}\right)+\lambda\left(i-i^{*}\right),
$$

where $\phi$ and $\lambda$ are both positive parameters (Rivera Bátiz and Rivera Bátiz, 1994). Equation (15) shows, first, that when foreign income is larger than domestic income, it results in an increase for demand of foreign currency in relation to the demand for domestic currency. In the same way, an increase in domestic interest rate acts as a brake in the growth of demand for domestic currency in relation to the demand for foreign currency, inducing local citizens to exchange money for bonds.

The final result for the determination of the exchange rate in the monetary approach becomes,

$$
\widehat{e}=\left(\widehat{M}-\widehat{M}^{*}\right)+\phi\left(\widehat{Y}^{*}-\widehat{Y}\right)+\lambda\left(i-i^{*}\right) .
$$

In our approach, and by using equation (11), the above equation becomes:

$$
\widehat{e}=\left(\widehat{M}-\widehat{M}^{*}\right)+\phi\left(\widehat{Y}^{*}-\widehat{Y}\right)+\lambda\left(i-i^{*}\right)+\left(\widehat{\beta}-\widehat{\beta}^{*}\right) .
$$




\section{The role of the expectations}

Expectations may be introduced in the model modifying the equation by the use of the uncovered interest rate parity condition (Rivera Batiz and Rivera Batiz, 1994).

$$
i-i^{*}=x=\frac{\bar{e}-e}{e}
$$

where $\bar{e}$ expresses the expected exchange rate. The above condition establishes the equality of the differential of domestic and foreign exchange rates with the expectation of devaluation for the domestic currency, that is, if we expected a devaluation in our currency, the foreign investor should receive a higher interest rate to compensate for devaluation. This equation does not take into account the compensation for the risk premium.

Assuming further that the economic agents are able to anticipate variations in exchange rates associated with the anticipated differentials between domestic, $\pi$, and foreign, $\pi^{*}$, inflation. Thus, we have,

$$
x=\pi-\pi^{*} .
$$

As a consequence, we may write

$$
\widehat{e}=\left(\widehat{M}-\widehat{M}^{*}\right)+\phi\left(\widehat{Y}^{*}-\widehat{Y}\right)+\lambda\left(\pi-\pi^{*}\right) .
$$

The first two terms of the equation have already been explained. The latter requires a little more attention. It illustrates that everything else being constant, an anticipated increase in domestic inflation depreciates the value of the domestic currency. The higher the anticipated inflation becomes, the higher the nominal domestic exchange rate turns, which reduces the real demand for domestic currency and requires a reduction in the value of the domestic currency to sustain the equilibrium. This point makes clear the important role about expectations in the monetary approach. Therefore, in our approach, equation (20) should be modified to:

$$
\widehat{e}=\left(\widehat{M}-\widehat{M}^{*}\right)+\phi\left(\widehat{Y}^{*}-\widehat{Y}\right)+\left(\widehat{\beta}-\widehat{\beta}^{*}\right)+\lambda\left(\pi-\pi^{*}\right) .
$$

In case of considering the uncovered interest rate parity, equation (21) should be modified in order to take into consideration the risk compensation $R$, so

$$
i=i^{*}+x-R \text {. }
$$

Hence, the corresponding equation in our proposal:

$$
\widehat{e}=\left(\widehat{M}-\widehat{M}^{*}\right)+\phi\left(\widehat{Y}^{*}-\widehat{Y}\right)+\left(\widehat{\beta}-\widehat{\beta}^{*}\right)+\lambda\left(\pi-\pi^{*}\right)-\lambda R .
$$




\section{Conclusions}

We should say that this theory is based itself on Hilferding's work (1981), where the distinction between values resulting from hours of labor in production and prices is essential. The theory eliminates the search (not yet answered) by the economists: what determines the relative values (exchange rates) of various fiat moneys; in a world without currency productivity this is what matters. In a world with currency (money), productivity and some variables expressed in money do matter. All because the value of currency, a relationship between the $G D P$ and hours spent to produce it cannot be distinct between two countries (as a long-run proposition). Our next step is to test the theory through empirical work.

\section{References}

Basso, L. F. C. (1987). Uma Crítica ao Conceito de Moeda como um Passivo das Autoridades Monetárias. XV Anais da Associação Nacional de Centro de Pós-Graduação em Economia (ANPEC).

Basso, L. F. C. (1988). Hilderfing e o Problema da Conceituação do Valor da Moeda. XVI Anais da Associação Nacional de Centros de Pós-Graduação em Economia (ANPEC). Belo Horizonte.

Basso, L. F. C. (1995). Viúvas da Desvalorización Cambial. Economia y Empresa. Universidade Mackenzie, 2(4).

Calvo, G. A. and C. A. Végh (1999). Inflation Stabilization and Balance-of-Payments Crises in Developing Countries. In J. Taylor and M. Woodford, eds. Handbook of Macroeconomics. North Holland.

Dornbush, R., and S. Fischer (1994). Macroeconomics. MacGraw-Hill, Inc. New York.

Dumenil, G. (1980). De la Valeur aux Prix de Production, Econômica, Paris.

Foley, D. (1982). The Value of Money, the Value of Labor Power and the Marxian Transformation Problem. Review of Radical Political Economy. Summer.

Franco, G. (1995). As Viúvas da Inflação, Folha de São Paulo. Primeiro Caderno, São Paulo.

Franco, G. (1998). A Inserção Externa e o Desenvolvimento. Revista de Economia Política. Julho, 18(3).

Hilferding, R. (1981). Finance Capital. Routledges \& Kegan Paul, London.

Kindleberger, C. O., and P. H. Lindert. (1983). International Economics. Richard D. Irwin, Inc., New York.

Rivera-Bátiz, F., and L. Rivera-Bátiz (1994). International Finance and Open Economy Macroeconomics. Prentice Hall, New York.

Tobin, J. (1998). Financial Globalization: Can National Currencies Survive? Annual World Bank Conference or Development Economics. Washington, D. C.

Venegas-Martínez, F. (2001). Temporary Stabilization: A Stochastic Analysis. Journal of Economic Dynamics and Control, 25(9), pp. 1429-1449. 